\title{
Ontogenetic dietary and habitat shifts in goliath grouper Epinephelus itajara from French Guiana
}

\author{
C. Artero ${ }^{1,2,4, *}$, C. C. Koenig ${ }^{2}$, P. Richard ${ }^{3}$, R. Berzins ${ }^{1}$, G. Guillou ${ }^{3}$, C. Bouchon ${ }^{4}$, \\ L. Lampert ${ }^{5}$
}

\author{
${ }^{1}$ Office National de la Chasse et de la Faune Sauvage, 44 rue Pasteur, BP 10808, 97338 Cayenne cedex, French Guiana \\ ${ }^{2}$ Florida State University Coastal and Marine Laboratory, 3618 Coastal Highway 98, St Teresa Beach, FL 32358, USA \\ ${ }^{3}$ Littoral Environnement et Sociétés, UMR 7266 CNRS-Université de La Rochelle, 2 rue Olympa de Gouges, \\ 17000 La Rochelle, France \\ ${ }^{4}$ Université des Antilles et de la Guyane, Labex CORAIL, équipe DYNECAR, 97159 Pointe à Pitre, \\ Guadeloupe (French West Indies) \\ ${ }^{5}$ Institut Français de Recherche pour l'Exploitation de la MER, Dyneco/Pelagos, 29280 Plouzané, France
}

\begin{abstract}
The ecology, particularly the trophic ecology, of the Critically Endangered goliath grouper Epinephelus itajara (Lichtenstein 1822) in French Guiana (France) is relatively unknown. Such information would provide a better understanding of the role that goliath groupers play in the marine ecosystem of French Guiana. This study focused on the feeding ecology of the goliath grouper through stomach-content and stable-isotope analyses of captured specimens. The dietary composition of goliath groupers in French Guiana was similar to that of goliath groupers from other areas of the species' range. However, in French Guiana, goliath groupers exhibited an ontogenetic shift in diet that has not been demonstrated elsewhere. Crustaceans, primarily crabs, were dominant in the diet of smaller individuals $(<120 \mathrm{~cm})$, whereas demersal fishes, particularly catfish (Siluriformes), dominated the diet of larger individuals. Analysis of $\delta^{13} \mathrm{C}$ and $\delta^{15} \mathrm{~N}$ in muscle samples indicated that: (1) larger fish fed more on higher trophic levels; (2) low seasonal and spatial variation existed in the diet; and (3) an apparent migration of early juveniles occurred from mangrove areas to rocky reefs. In French Guiana, adult and juvenile goliath groupers share marine rocky habitat, and the data suggest they may avoid food competition by a shift in diet with size.
\end{abstract}

KEY WORDS: Epinephelidae $\cdot$ Critically Endangered species $\cdot$ Stomach contents $\cdot$ Carbon and nitrogen stable isotopes $\cdot$ Dietary shift $\cdot$ Migration $\cdot$ Mangroves $\cdot$ Diet

\section{INTRODUCTION}

Goliath grouper Epinephelus itajara (Lichtenstein 1822) is a long-lived, slow-growing species living in tropical and subtropical waters of the Atlantic Ocean and the largest reef fish in the western Atlantic (Sadovy \& Eklund 1999). The species is listed as 'Critically Endangered' in the IUCN Red List of Threatened Species, primarily because of overfishing (Craig 2011). The loss of $95 \%$ of the population (McClenachan 2009) led to a total fishing ban in the southeastern USA in 1990 (NMFS 2006) and in Brazil

${ }^{*}$ Corresponding author: celine.artero.merou@gmail.com in 2002 (Hostim-Silva et al. 2005). From Florida to Brazil, there have been a number of studies on goliath grouper, including age and growth (Bullock et al. 1992, Lara et al. 2009, Murie et al. 2009), and migration (Pina-Amargós \& González-Sansón 2009). Limited dietary information exists on the species throughout its range. However, observations have provided some insight into the diet of goliath grouper, suggesting that it prefers crustaceans and slowmoving fishes (Longley \& Hildebrand 1941, Randall 1983), but also feeds on other species, including octopus, gastropods, echinoderms and turtles (Bullock \&

() The authors 2015. Open Access under Creative Commons by Attribution Licence. Use, distribution and reproduction are unrestricted. Authors and original publication must be credited. 
Smith 1991, Gerhardinger et al. 2006). Their dentition is comprised of small sharp teeth designed to hold prey, and their general morphology includes stout muscular bodies with very large mouths. Their powerful body allows short bursts of speed over limited distances (Bullock \& Smith 1991). This, combined with suction feeding, makes them effective predators at close range, but does not adapt them for chasing pelagic prey (Randall 1983, Bullock \& Smith 1991, Sadovy \& Eklund 1999). Because of their large adult size (max. $250 \mathrm{~cm}$ ), goliath grouper are prey for relatively few species, but large sharks may prey on them (Sadovy \& Eklund 1999).

Goliath grouper inhabit rocky habitats in French Guiana (South America, France) where they are relatively abundant compared to other areas of the Caribbean and support small commercial and recreational fisheries. The marine environment off French Guiana is under the influence of the Amazon River; sediments are transported to the north of the Amazon and all along the Guiana shelf by the North Brazil Current (Gratiot et al. 2008), making local marine waters extremely turbid and leading to low salinity. Although there is an abundance of marine organisms in this area, the ecology of these organisms, including goliath grouper, is poorly known.

The objective of this study was to investigate the feeding ecology of goliath grouper in the coastal waters off French Guiana using stomach contents and stable-isotope analyses of muscle samples. Stomachcontent analysis provides some indication of the species preyed upon, and stable isotopes provide an integrated view of long-term trophic patterns (Pinnegar \& Polunin 1999). Because many dietary analysis studies have revealed ontogenetic dietary shifts in a number of species (Cocheret de la Morinière et al. 2003, Burress et al. 2013), including grouper species (Derbal \& Kara 1996, Eggleston et al. 1998, Reñones et al. 2002, Linde et al. 2004), the present study aimed to compare the diet within a wide size range $(62$ to $194 \mathrm{~cm})$.

Individuals $<120 \mathrm{~cm}$, considered juveniles, and individuals $>120 \mathrm{~cm}$, considered adults (Bullock et al. 1992), occur in the same habitats in French Guiana. Elsewhere, distinct habitats are identified for each life stage: juveniles occupy mangroves, considered to be essential habitat during their first $5 \mathrm{yr}$ of life (Koenig et al. 2007), and adults are found in marine environments offshore (Sadovy \& Eklund 1999, Koenig \& Coleman 2009). Depending on the tissue turnover rate and differences in baseline isotopic signature among habitats and because isotopic signatures in animal tissues reflect local food-web patterns, stable isotope ratios can also be used to detect movements of organisms from one habitat to another (Fry et al. 1999, Hobson 1999). Therefore, the second objective of this study was to investigate the link between dietary information and habitat shifts.

\section{MATERIALS AND METHODS}

\section{Sampling and study areas}

Field work was carried out from April 2010 to December 2012, during 3 rainy seasons (December to June) and 3 dry seasons (July to November). It was not possible to sample from January to March of each year because of poor sea conditions. Goliath grouper specimens were caught with fishing rods around 3 rocky sites (Ilets Rémire, Battures and Grand Connétable island reserve) along the French Guiana coast (Fig. 1) where depths vary from 2-5 m (Ilets Rémire) to $20 \mathrm{~m}$ (Battures), with 6 to $9 \mathrm{~m}$ at the reserve. All fishing was done during the day (07:00 to 17:00 h).

Length $( \pm 1 \mathrm{~cm})$ was measured as the straight-line distance from the tip of the upper jaw to the end of the tail (total length, $L_{\mathrm{T}}$ ). All captured goliath grouper were sampled (stomach content or tissue sample or both), tagged and released alive.

Two non-lethal methods of sampling stomach contents were used (Kamler \& Pope 2001) on 154 specimens $(125 \pm 23 \mathrm{~cm})$ of goliath grouper: (1) stomach contents were flushed out of the stomach of fish $<120 \mathrm{~cm} L_{\mathrm{T}}$ with a water pump and (2) stomach contents of fish $>120 \mathrm{~cm} L_{\mathrm{T}}$ were directly removed by gloved hand. Stomach contents were kept on ice in plastic bags and then frozen $\left(-20^{\circ} \mathrm{C}\right)$ until dietary items could be identified and quantified.

White muscle biopsied from the base of dorsal fin rays was used for analysis of stable isotopes. This tissue is considered to be one of the best for use in ecological work (Pinnegar \& Polunin 1999), because of its relatively low carbon turnover rate (Guelinckx et al. 2007, Buchheister \& Latour 2010, Ankjærø et al. 2012).

Fish species assumed to be potential prey of goliath grouper were collected in the same rocky habitat as goliath grouper, and their dorsal muscles were analysed along with goliath grouper muscle. Muscle tissues from crustaceans found in stomach contents were also analysed. Sediment organic matter (SOM) and algae were also examined. All stable isotopes samples were stored frozen $\left(-20^{\circ} \mathrm{C}\right)$ in a microtube until they were freeze dried and ground to fine powder. 


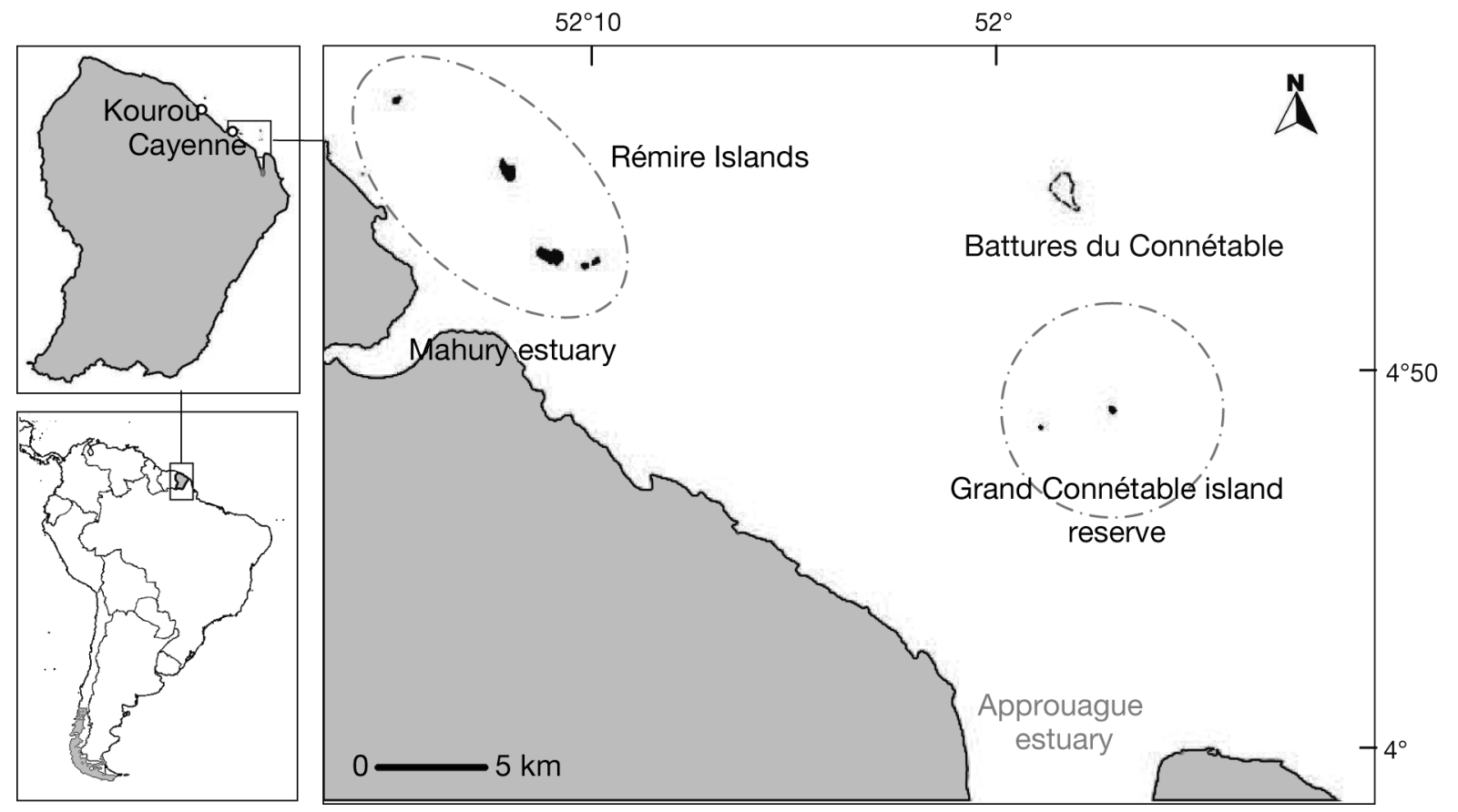

Fig. 1. Study sites in French Guiana. White delimited zone: submerged rock; black zones: rocky islands

\section{Stomach-content analysis}

Stomach contents were blotted dry and weighed $( \pm 0.1 \mathrm{~g})$. The composition of the diet was analysed according to recommendations by Hyslop (1980). First, frequency of occurrence $(\% F=100 \times$ number of stomachs with a prey item $i$ / total number of stomachs with prey items), numerical composition $(\% N=$ $100 \times$ number of prey items $i$ / total number of prey items) and weight composition $(\% W=100 \times$ weight of a prey item $i$ / total weight of prey items) were calculated. According to Liao et al. (2001) these 3 indices were combined in the index of relative importance IRI $=(\% N+\% W) \times \% F($ Pinkas et al. 1971) expressed as a percentage (Cortés 1997). Prey items were classified by ranking \%IRI values in descending order (Rosecchi \& Nouaze 1987): preferential prey $\left(\sum \% \mathrm{IRI}=50\right)$, secondary prey $\left(50<\sum \% \mathrm{IRI} \leq 75\right)$ and occasional prey $\left(\sum \%\right.$ IRI $\left.>75\right)$.

Prey items were identified to the lowest possible taxon following Fischer (1978), Takeda \& Okutani (1983) and Léopold (2005). The vacuity coefficient $\left(V_{\mathrm{c}}=100 \times\right.$ number of empty stomachs / total sampled stomachs) was calculated, and a reference collection of local fish skeletons of partially digested prey items was made so as to facilitate identification of heavily digested prey items. Degree of digestion was classified into 6 categories according to Zuev et al. (1985).
The diet of goliath grouper was analysed relative to length. Goliath groupers measuring from 73 to $189 \mathrm{~cm}$ were separated into $9-10 \mathrm{~cm}$ size classes from $<80$ to $>150 \mathrm{~cm}$.

For comparisons among sizes, and to avoid biases induced by the differential digestion rates, numerical composition of prey was used. Food overlap among goliath grouper size classes was evaluated using Morisita's index (Morisita 1959) as modified by Horn (1966).

Levins' index was used to measure niche breadth $\left(B=1 / \Sigma P_{i}^{2}\right)$, where $P_{i}$ is the proportion of item $i$, and its standardized measure $\left[B_{\mathrm{A}}=(B-1) /\right.$ (number of prey -1)] (Krebs 1989). This measure ranges from 1 to the number of prey categories, whereas Levins' standardized measure ranges from 0 to 1 ; low values indicate a diet dominated by a few prey items (specialist predator), while higher values indicate a generalist diet (Navia et al. 2007).

Graphical methods by Costello (1990) were used to illustrate the relative importance of prey species and to assess the feeding strategy. This method was further developed by Tokeshi (1991) in order to improve the feeding strategy interpretation: specialist (feed on few prey species) or generalist (feed on many prey species). Generalist feeders could have a homogeneous feeding strategy (all individuals in the population feed on many prey species) or a heterogeneous feeding (individuals feed on different prey species). 
For this, individual feeding diversity (ID $=-\sum P_{i j} \ln P_{i j} /$ total number of individuals) and population feeding diversity ( $\mathrm{PD}=-\sum P_{i} \ln P_{i}$ ) were calculated. $P_{i j}$ is the proportion of prey $i$ in the individual $j$, and $P_{i}$ is proportion of prey $i$ in the entire sampled population.

\section{Tissue sample preparation and analysis}

\section{Lipid extraction}

Lipid extractions were done because variable proportions of lipids in tissue samples distorts $\delta^{13} \mathrm{C}$ values (Focken \& Becker 1998), since lipids are depleted in ${ }^{13} \mathrm{C}$ compared to other components (DeNiro \& Epstein 1977). Lipids were extracted from white muscles using cyclohexane (Chouvelon et al. 2011). Two cycles of extraction $(1 \mathrm{~h}$ agitation of $100 \mathrm{mg}$ white muscle with $4 \mathrm{ml}$ of cyclohexane followed by centrifugation $\left[10^{\circ} \mathrm{C}, 1200 \times g, 10 \mathrm{~min}\right]$ to easily discard the supernatant) were performed before drying the pellet in a $40^{\circ} \mathrm{C}$ dry bath for $12 \mathrm{~h}$. The C:N ratio is a good indicator of lipid content in aquatic animals (Post 2002). Because C:N values of prey were $<4$ $\left(<10 \%\right.$ lipid content), $\delta^{13} \mathrm{C}$ values of prey samples without lipid extraction would not have been biased significantly. So lipids were removed from goliath grouper tissue (164 individuals from 62 to $194 \mathrm{~cm}$ ) but not from the tissue of prey items (34 crustaceans and 78 teleosts).

\section{Acidification}

Because inorganic carbonate is depleted in ${ }^{13} \mathrm{C}$ relative to other fractions, it may interfere with isotopic determinations in organic fractions (DeNiro \& Epstein 1978). To avoid this interference, samples containing calcium carbonate, such as SOM, were acidified by inserting $2 \mathrm{~N} \mathrm{HCl}$ in sediment (Fry 1988, Nieuwenhuize et al. 1994). To minimize errors in estimating $\delta^{13} \mathrm{C}$ values, samples were not rinsed (Jacob et al. 2005). Nitrogen content is affected by acid washing (Bunn et al. 1995), so SOM samples were duplicated to measure the $\delta^{15} \mathrm{~N}$ value of non-acidified samples.

Stable isotope ratio measurement

Dry samples were weighed in tin cups $(0.4 \pm 0.1 \mathrm{mg}$ for fish muscle samples, $1.4 \pm 0.1 \mathrm{mg}$ for algae and 5 $\pm 0.5 \mathrm{mg}$ for SOM). Analyses were performed using a
Thermo Scientific Flash EA1112 elemental analyser coupled to a Delta V Advantage mass spectrometer (Thermo Scientific). Results are expressed in the usual delta notation $(\delta)$ as parts per thousand $(\%)$ relative to an international standard (Vienna Pee Dee Belemnite for carbon, atmospheric $\mathrm{N}_{2}$ for nitrogen) (Fry 2006):

$$
\delta X=\left[\left(R_{\text {sample }}-R_{\text {standard }}\right) / R_{\text {standard }}\right] \times 10^{3}
$$

where $X$ is ${ }^{13} \mathrm{C}$ or ${ }^{15} \mathrm{~N}$, and $R$ is the corresponding ratio, i.e. ${ }^{13} \mathrm{C}:{ }^{12} \mathrm{C}$ or ${ }^{14} \mathrm{~N}:{ }^{15} \mathrm{~N}$. Based on replicate measurements of internal laboratory standards, precision was better than 0.15 and $0.20 \%$ for $\delta^{13} \mathrm{C}$ and $\delta^{15} \mathrm{~N}$, respectively.

\section{Fractionation and turnover rate}

Isotope fractionation is the difference in $\delta^{13} \mathrm{C}$ and $\delta^{15} \mathrm{~N}$ values between the diet and consumer (DeNiro \& Epstein 1978, Post 2002). Carbon and nitrogen fractionation $\left(\Delta \delta^{13} \mathrm{C}\right.$ and $\left.\Delta \delta^{15} \mathrm{~N}\right)$ are reported in reviews at 0.8 to $1 \%$ and $3.4 \%$, respectively, at each trophic step (DeNiro \& Epstein 1978, Post 2002). These values are debatable (Sweeting et al. 2007), but well accepted for carnivorous species, so interpretations of the results were based on these theoretical values.

Another important parameter when working with stable isotopes is the period required for the isotopic signature to reach equilibrium with the food source, usually termed the turnover rate (Hobson \& Clark 1992). The half-life value $\left(t_{1 / 2}\right)$ is conventionally used to express the isotopic turnover rate (Tieszen et al. 1983), i.e. the amount of time (days) required to reach the midpoint value of the initial and equilibrium values (Guelinckx et al. 2007).

$$
t_{1 / 2}=\ln (2) / \lambda
$$

Based on data in the literature, Weidel et al. (2011) found that the carbon turnover rate $(\lambda)$ in white muscles is linked to fish weight $(\mathrm{g}): \ln (\lambda)=-3.65-0.2 \ln$ (weigh). In this case, it is possible to calculate the half-life from the weight $(W)$ of the fish.

$$
t_{1 / 2 \text { carbon }}=\ln (2) / \exp [-3.65-0.2 \ln (W)]
$$

\section{Statistical analysis}

For stomach-content analysis, a constrained ordination technique, redundancy analysis (RDA), was 
carried out in order to highlight the main factors involved in feeding variation. Both spatiotemporal (sites, substrate, seasons, month, year) and somatic (size) factors were evaluated. RDA was worked out using Bray-Curtis distance with the Vegan library of $\mathrm{R}$ software (www.r-project.org). The proportions of prey types were compared with a chi-squared test. Biplots of $\delta^{13} \mathrm{C}$ and $\delta^{15} \mathrm{~N}$ values were used to examine the proximity of goliath groupers to potential prey and source signatures. A 1-way ANOVA was performed to analyse both temporal and spatial variations in isotopic signatures and the effect of size on isotopic ratios. In the absence of normality and equality of variance, means were compared using nonparametric tests (Wilcoxon or Kruskal-Wallis analysis of variance of ranks for multiple samples), and the Kendall rank correlation coefficient was used to compare dietary factors.

\section{RESULTS}

\section{Goliath grouper diet composition revealed by stomach-content analysis}

Most of the stomach-content samples $(\mathrm{n}=133)$ came from the island of Grand Connétable reserve, compared to 16 from Ilets Rémire and 5 from Battures. Forty-four percent were empty, leaving a total of 87 stomach samples with contents 73 from the island of Grand Connétable reserve, 10 from Ilets Rémire and 4 from Battures). Sixty-six percent of the samples with food contained 1 prey item, $20 \%$ had 2 prey items and $14 \%$ had $>2$ prey items.

Main groups of prey. The 150 prey items collected in goliath grouper stomachs were comprised of 49 species that can be divided into 2 main groups: teleosts (30 species) and crustaceans (17 species). Only 3 specimens of gastropods and cnidarians (1 species each) were found.

Among the prey items collected, 54 were teleosts $(\% N=36 \%)$ and 93 were crustaceans $(\% N=62 \%)$, but because of the size and mass of these 2 prey types, teleosts could be considered as the major part of the diet of sampled goliath groupers (IRI $=59 \%$ ) followed by crustaceans (IRI $=41 \%$ ) (Fig. 2).

With respect to teleosts, goliath grouper ate mainly catfish, i.e. Siluriformes $(\% N=82.5 \%)$, followed by Perciformes $(\% N=10 \%)$, Tetraodontiformes $(\% N=$ $5 \%)$ and Clupeiformes ( $\% N=2.5 \%)$.

Of the crustaceans, Decapoda and Reptantia (crabs) are the main taxon ingested, with $93 \%$, followed by Natantia (shrimp), with $7 \%$. Crabs obser- ved in stomachs mainly belonged to 2 families: Xanthidae (IRI $=34.7 \%$ ) and Portunidae (IRI $=17 \%$ ).

At the species level, the principal prey items were the Xanthidae (sp.1) (\%IRI = 30) and Portunidae (Cronius ruber $)(\% \mathrm{IRI}=21)$. The ariid catfish Aspitor quadriscutis $(\% \mathrm{IRI}=17)$ was the third most important prey item eaten by goliath groupers. The other ariid Hexanematichthys couma (\%IRI = 7) can be considered secondary prey. All other prey species were occasionally consumed (Fig. 2).

Niche breadth and feeding behaviour. The Levins index of niche breadth was equal to $13.6(\mathrm{n}=49)$. The time of day was not related to stomach status (full or empty) (Kendall rank correlation: $\tau=0.014, \mathrm{n}=154$, $\mathrm{p}=0.82)$ nor to the degree of digestion $\left(\mathrm{R}^{2}=10^{-5}\right)$. There was no significant correlation between tidal stage and stomach status (Kendall rank correlation: $\tau=0.01, \mathrm{n}=154, \mathrm{p}=0.86$ ) or degree of digestion (Kendall rank correlation: $\tau=-0.06, \mathrm{n}=134, \mathrm{p}=0.3$ ).

Factors influencing the feeding ecology of goliath grouper. The abiotic variables (site, month, season, year, depth, sea condition, weather) introduced in the RDA explained only $12 \%$ of the variance in the goliath groupers' diet. The main factor explaining the observed variance was fish size $(37 \%)$.

\section{Size-related variation in goliath grouper diet}

Proportion of empty stomachs. The vacuity index increased significantly with fish size (chi-squared

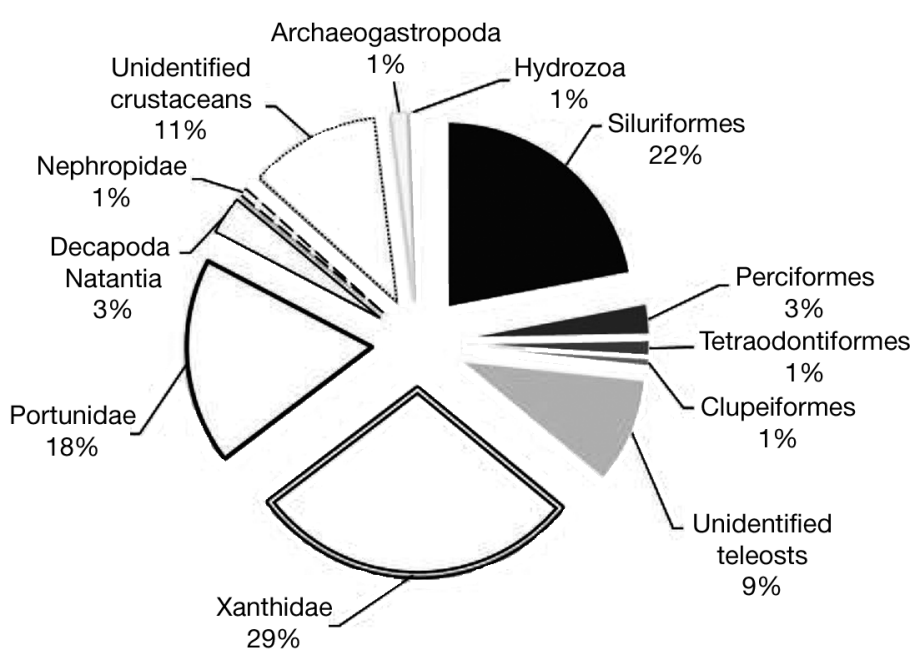

Fig. 2. Percentage of the number of each type of prey found in goliath grouper (Epinephelus itajara) stomach contents (n = 87) in French Guiana between April 2010 and December 2012. Prey are teleosts (grey to black shading), crustaceans (white), gastropods and cnidarians (grey outline) 
test: $\left.\chi^{2}=27.55, \mathrm{n}=154, \mathrm{p}<0.05\right)$. Small fish had a significantly lower proportion of empty stomachs than larger fish (Fig. 3).

Number of prey. The mean number of prey items in stomachs of goliath grouper decreased with size (Kendall rank correlation: $\tau=-0.7, \mathrm{n}=86, \mathrm{p}=0.004$ ) (Fig. 4). Individuals measuring $<120 \mathrm{~cm}$ generally had $>2$ prey items and individuals $>120 \mathrm{~cm}$ rarely had more than 1 prey item in their stomachs.

Main groups of prey. There was a significant ontogenetic change in the diet of goliath grouper in French Guiana. The diet changed from crustaceandominated to fish-dominated over the size classes examined $\left(\chi^{2}=58.69, \mathrm{n}=145, \mathrm{p}<0.05\right)$. The proportion of crustaceans decreased among size classes (Kendall rank correlation: $\tau=-0.81, \mathrm{n}=9, \mathrm{p}=0.002$ ), while the proportion of teleosts increased $(\tau=-1, \mathrm{n}=$ $9, p=0.0002)$. Teleosts became more common in the diet at about $90 \mathrm{~cm} L_{\mathrm{T}}$, and goliath groupers were completely piscivorous by $140 \mathrm{~cm} L_{\mathrm{T}}$ (Fig. 5). Only 2 crustaceans were found in the 21 stomachs of individuals $>140 \mathrm{~cm} L_{\mathrm{T}}$.

The similarity of prey species among small size classes of goliath grouper was strong (Table 1). Indeed, small goliath groupers selected the same prey species, primarily the portunid Cronius ruber and xanthid crabs. Morisita's index was low when comparing the $<80 \mathrm{~cm}$ size class with others, because many prey items were categorized as unidentified crustaceans.

The similarity index was not significant among the larger size classes. Nine of the 10 index values among individuals $>110 \mathrm{~cm}$ were $<0.6$ (Table 1 ).

Niche breadth and feeding strategy. Levins' breadth index yielded the greatest diet breadth for goliath grouper measuring between 140 and $150 \mathrm{~cm}$, while the smallest size classes $(<90 \mathrm{~cm})$ were the

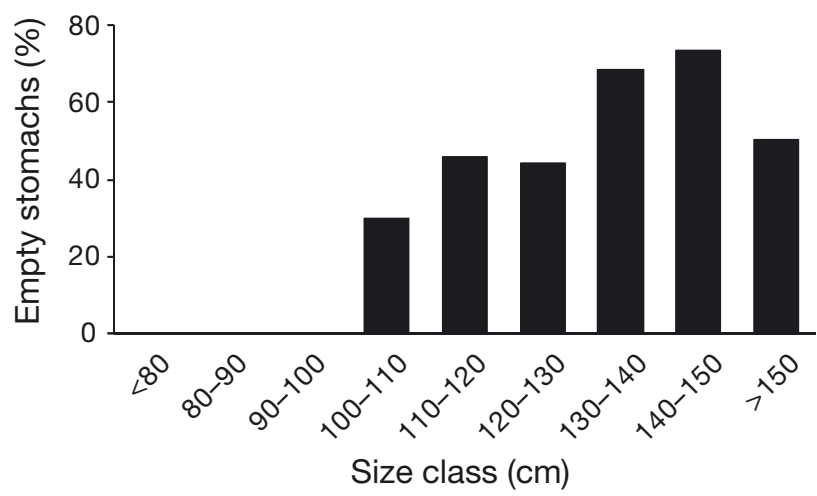

Fig. 3. Percent of empty stomachs among goliath grouper (Epinephelus itajara) size classes (total length, $\mathrm{cm}$ ) in French Guiana $(\mathrm{n}=154)$

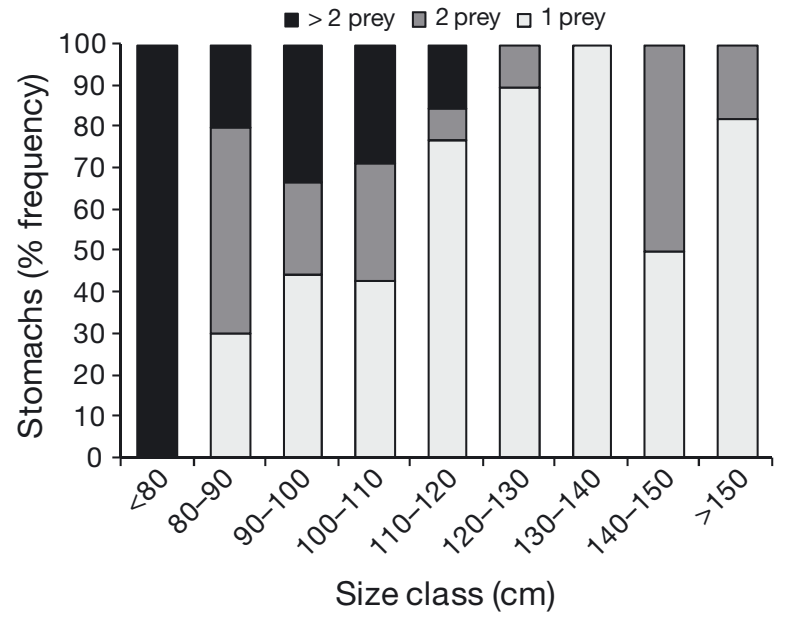

Fig. 4. Percent frequency of prey items per stomach among size classes (total length, $\mathrm{cm}$ ) of goliath grouper (Epinephelus itajara) in French Guiana $(\mathrm{n}=87)$

most specialized predators (Table 2). Overall, groupers $>120 \mathrm{~cm}$ had a greater niche breadth than small groupers.

The Tokeshi representation elucidated several ontogenetic feeding strategies. Individuals from 80 to $110 \mathrm{~cm}$ were generalists, consuming few principal prey species, whereas goliath groupers $>110 \mathrm{~cm}$, also generalists, fed on a wide diversity of species (Fig. 6).

\section{Stable isotope composition of goliath grouper}

Values of $\delta^{13} \mathrm{C}$ and $\delta^{15} \mathrm{~N}$ in French Guiana goliath groupers ranged from -18.9 to $-11.5 \%$ and 11.3 to $15.7 \%$, respectively (Fig. 7 ).

The half-life varied from $151 \mathrm{~d}$ for a $6 \mathrm{~kg}$ fish $(\sim 70 \mathrm{~cm})$ to $289 \mathrm{~d}$ for a $150 \mathrm{~kg}$ fish $(\sim 195 \mathrm{~cm})$. Thus, in

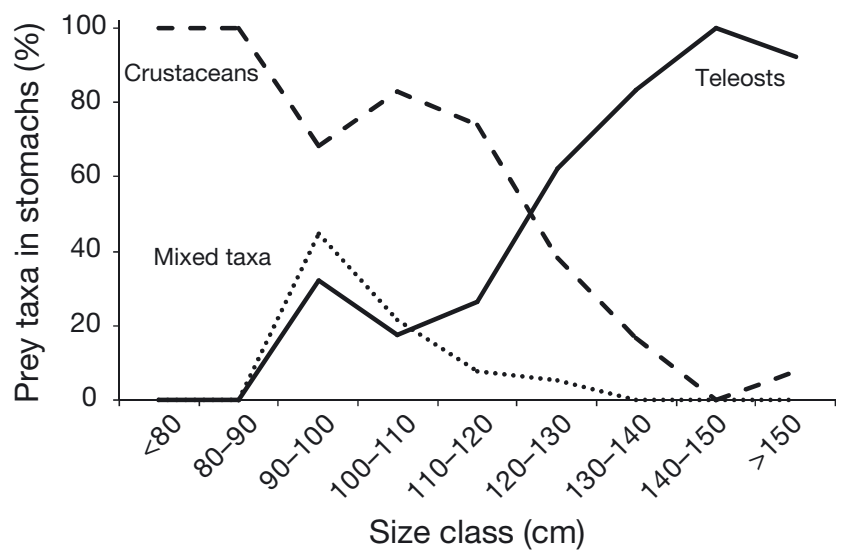

Fig. 5. Percent of crustacean and teleost taxa and mixed taxa (presence of both crustaceans and teleosts) in stomach contents of goliath grouper Epinephelus itajara by size class (total length, cm) in French Guiana 
Table 1. Morisita similarity index comparing the diets of goliath grouper (Epinephelus itajara) of various size classes (total length, cm) in French Guiana. Groups of prey (crustaceans and teleosts) are shown below the diagonal, and prey species (e.g. Ascitor quadriscutis) are above the diagonal. Significant (index >0.6) similarities are in bold

\begin{tabular}{|lccccccccc|}
\hline Size classes & $<80$ & $80-90$ & $90-100$ & $100-110$ & $110-120$ & $120-130$ & $130-140$ & $140-150$ & $>150$ \\
\hline$<80$ & - & 0.06 & 0.00 & 0.12 & 0.27 & 0.09 & 0.00 & 0.00 & 0.16 \\
$80-90$ & $\mathbf{0 . 9 4}$ & - & $\mathbf{0 . 6 2}$ & $\mathbf{0 . 7 8}$ & $\mathbf{0 . 6 7}$ & 0.32 & 0.00 & 0.00 & 0.02 \\
$90-100$ & $\mathbf{0 . 8 5}$ & $\mathbf{0 . 8 9}$ & - & $\mathbf{0 . 7 1}$ & $\mathbf{0 . 7 0}$ & 0.37 & 0.03 & 0.00 & 0.06 \\
$100-110$ & $\mathbf{0 . 9 6}$ & $\mathbf{0 . 9 7}$ & $\mathbf{0 . 9 6}$ & - & $\mathbf{0 . 8 1}$ & 0.47 & 0.02 & 0.04 & 0.11 \\
$110-120$ & $\mathbf{0 . 9 1}$ & $\mathbf{0 . 9 3}$ & $\mathbf{0 . 9 9}$ & $\mathbf{0 . 9 9}$ & - & 0.00 & 0.00 & 0.16 \\
$120-130$ & 0.50 & 0.52 & $\mathbf{0 . 8 5}$ & $\mathbf{0 . 6 8}$ & 0.00 & - & 0.08 & 0.37 \\
$130-140$ & 0.19 & 0.19 & $\mathbf{0 . 6 0}$ & 0.39 & 0.51 & $\mathbf{0 . 9 3}$ & - & 0.00 & 0.06 \\
$140-150$ & 0.00 & 0.00 & 0.42 & 0.20 & 0.33 & $\mathbf{0 . 8 1}$ & $\mathbf{0 . 9 7}$ & - & 0.49 \\
$>150$ & 0.10 & 0.10 & 0.52 & 0.30 & 0.42 & $\mathbf{0 . 8 8}$ & $\mathbf{0 . 9 9}$ & $\mathbf{0 . 9 9}$ & - \\
\hline
\end{tabular}

this study, it can be assumed that the carbon turnover rate is around $1 \mathrm{yr}$.

There was no significant difference in mean values of $\delta^{13} \mathrm{C}$ and $\delta^{15} \mathrm{~N}$ among years (ANOVA: $F_{\mathrm{C}}=0.76, \mathrm{n}=$ $\left.164, \mathrm{p}>0.05 ; F_{\mathrm{N}}=0.51, \mathrm{n}=164, \mathrm{p}>0.05\right)$, seasons

Table 2. Niche breadth of size classes (total length, $\mathrm{cm}$ ) of goliath groupers (Epinephelus itajara) in French Guiana. Values shown are Levins' measure of niche breadth $(B)$ and standardized Levins' measure of niche breadth $\left(B_{\mathrm{A}}\right)$. NT: total number of prey categories used

\begin{tabular}{|lrrc|}
\hline Size class & NT & $B$ & $B_{\mathrm{A}}$ \\
\hline$<80$ & 2 & 1.28 & 0.28 \\
$80-90$ & 10 & 4.50 & 0.40 \\
$90-100$ & 16 & 9.33 & 0.56 \\
$100-110$ & 14 & 7.37 & 0.49 \\
$110-120$ & 10 & 5.91 & 0.54 \\
$120-130$ & 15 & 11.52 & 0.75 \\
$130-140$ & 4 & 3.00 & 0.66 \\
$140-150$ & 7 & 7.00 & 1.00 \\
$>150$ & 11 & 8.89 & 0.78 \\
\hline
\end{tabular}

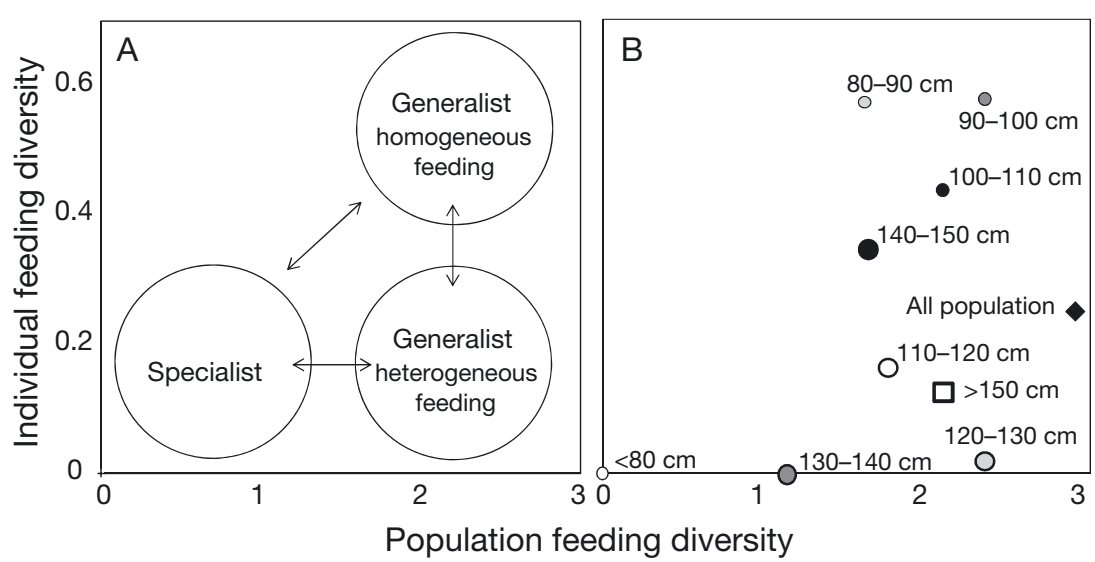

Fig. 6. (A) Scheme for the interpretation of the Tokeshi graphical method (after Tokeshi 1991). (B) Scatterplot of goliath grouper (Epinephelus tajara) size classes (total length, $\mathrm{cm})$ according to the method in $(\mathrm{A})(\mathrm{n}=87)$. Each size class is represented by a different symbol
(ANOVA: $F_{\mathrm{C}}=2.92, \mathrm{n}=164, \mathrm{p}>0.05 ; F_{\mathrm{N}}=0.18, \mathrm{n}=$ 164, $\mathrm{p}>0.05$ ), or study sites (Wilcoxon: $\mathrm{n}=164$, $\mathrm{p}>$ $0.05)$.

Values of $\delta^{13} \mathrm{C}$ increased with goliath grouper size (Kendall rank correlation: $\tau=0.32, \mathrm{n}=164, \mathrm{p}<0.05$ ) (Fig. 7B). The variation in $\delta^{13} \mathrm{C}$ values was large for groupers $<130 \mathrm{~cm}$ (from -18 to $-11.5 \%$ ) but declined with size from -15 to $-11.5 \%$ in larger groupers. Maximum $\delta^{13} \mathrm{C}$ values were stable around $-12 \%$ across all fish size classes. The $\delta^{15} \mathrm{~N}$ values also increased with size (Kendall rank correlation: $\tau=0.47$, $\mathrm{n}=164, \mathrm{p}<0.05$ ) (Fig. 7A).

\section{Stable isotope composition among prey}

Mean values of $\delta^{13} \mathrm{C}$ and $\delta^{15} \mathrm{~N}$ for collected crustacean prey were $-15.2 \pm 1.2 \%$ and $9.7 \pm 0.9 \%$, respectively. Mean values of $\delta^{13} \mathrm{C}(-14.9 \pm 0.9 \%)$ for collected teleost prey were similar to those of crustaceans, whereas mean values of $\delta^{15} \mathrm{~N}$ were slightly higher $(11.5 \pm$ $0.9 \%$ ). Sediment had a $\delta^{13} \mathrm{C}$ equal to $-24.37 \%$ and a $\delta^{15} \mathrm{~N}$ equal to $3.2 \%$. Isotopic signatures of primary producers, algae, were $-17.6 \pm 0.4 \%$ for $\delta^{13} \mathrm{C}$ and $4.7 \pm 1.7 \%$ o for $\delta^{15} \mathrm{~N}$ (Fig. 8).

Mean values of $\delta^{13} \mathrm{C}$ for crustacean prey items were not significantly different among sites (Kruskal-Wallis test: $\mathrm{KW}=0.03, \mathrm{n}=$ $34, \mathrm{p}>0.05)$ or seasons $(\mathrm{KW}=3.39$, $\mathrm{n}=34, \mathrm{p}>0.05) . \delta^{15} \mathrm{~N}$ mean values of crustacean prey items were not different among sites $(\mathrm{KW}=0.26$, $\mathrm{n}=34, \mathrm{p}>0.05$ ) and seasons (KW = 0.82, $\mathrm{n}=34, \mathrm{p}>0.05$ ). 


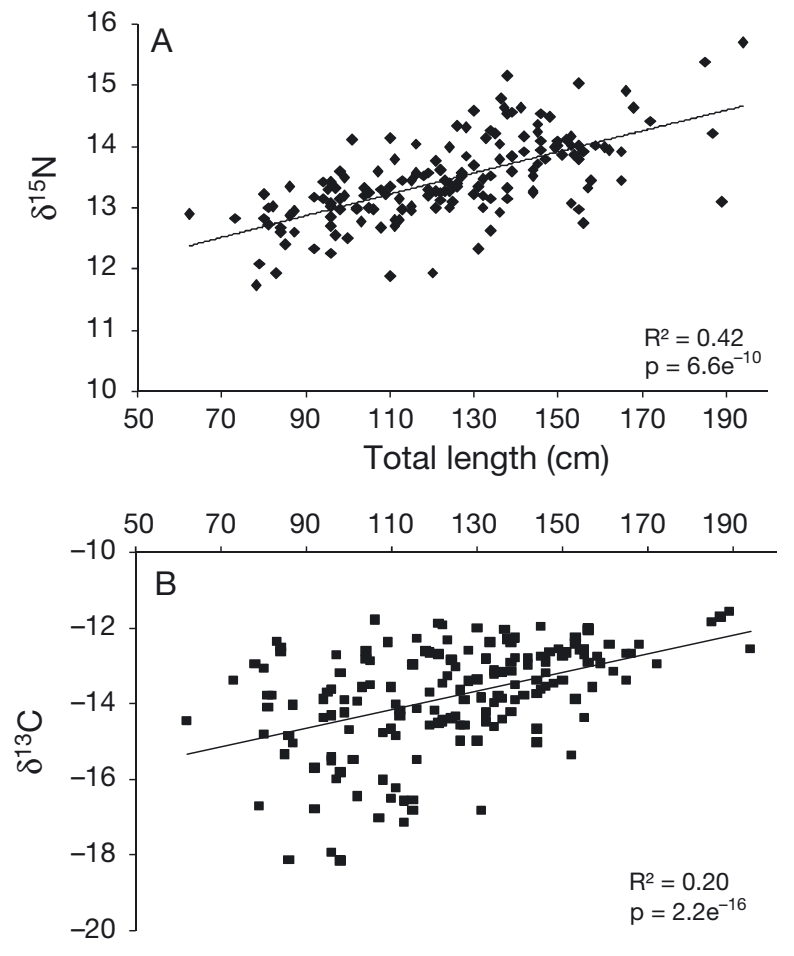

Fig. 7. Change in (A) $\delta^{15} \mathrm{~N}$ and (B) $\delta^{13} \mathrm{C}$ values of goliath grouper Epinephelus itajara by size (total length, $\mathrm{cm}$ ) in French Guiana

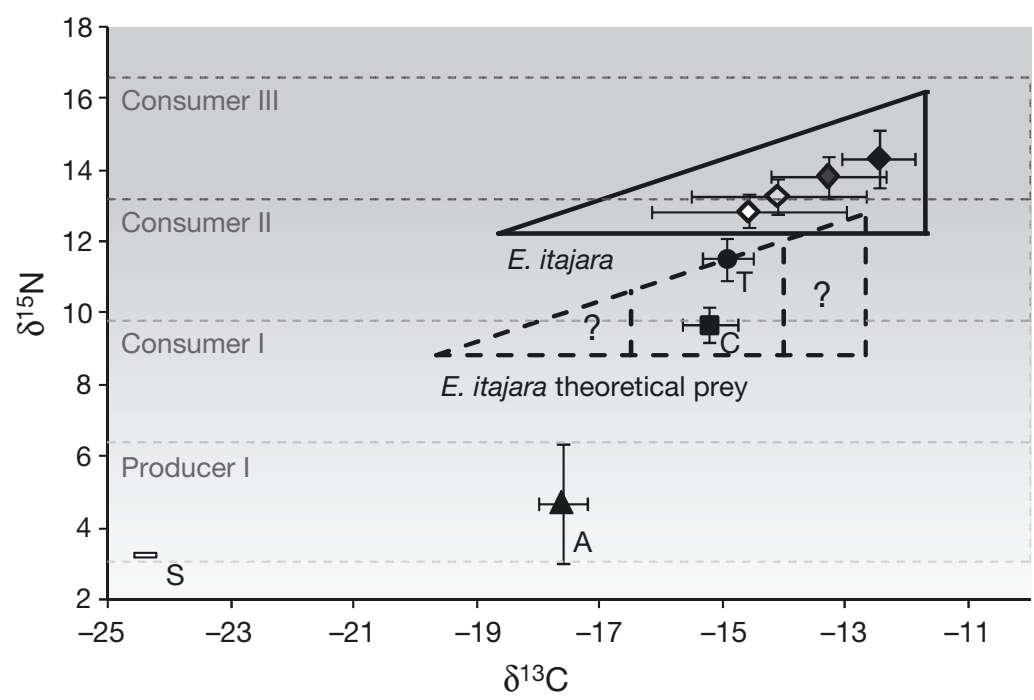

Fig. 8. Isotopic signatures of goliath groupers and their prey. Solid, large triangle: range values of carbon and nitrogen stable isotopes of goliath grouper; dashed, large triangle: theoretical isotopic signatures of prey items based on fractionation values $(+1 \%$ for carbon and $+3.4 \%$ for nitrogen). Goliath grouper size classes are represented by diamonds: white $(<100 \mathrm{~cm})$, light grey $(100-120 \mathrm{~cm})$, dark grey $(120-150 \mathrm{~cm})$ and black $(\geq 150 \mathrm{~cm})$. The filled circle, square, triangle and rectangle represent the mean isotopic values of teleosts (T), crustaceans (C), algae (A) and sediment (S), respectively, with standard error bars. ?: unidentified species; Producer I: algae; Consumer I: predator of algae; Consumer II: predator of Consumer I; Consumer III: predator of Consumer II
Carbon and nitrogen isotope signatures in fish prey were not significantly different between sites $\left(\mathrm{KW}_{\delta^{13} \mathrm{C}}=4.05, \mathrm{n}=78, \mathrm{p}>0.05 ; \mathrm{KW}_{\delta^{15 \mathrm{~N}}}=4.01, \mathrm{n}=78\right.$ $p>0.05)$. Seasonal variation could not be tested befish prey were sampled only during the dry ath grouper $\delta^{13} \mathrm{C}$ and $\delta^{15} \mathrm{~N}$ values exists because

Stomach contents and stable-isotope values highlight that goliath grouper in French Guiana consumes 2 main prey groups: teleosts and crustaceans. Cnidarians and gastropods are considered occasional prey species. In stomach contents, teleosts are nuans, making teleosts a major prey grour studies also indicate that goliath groupers feed 1983, vertebrates and invertebrates (Randall 1967, 1983, Odum 1971, Bullock \& Smith 1991, Sadovy \& Eklund 1999). The diet of goliath groupers in French Guiana is somewhat similar to that shown in prior studies in other regions of their range (Odum 1971, Bullock \& Smith 1991). However, in some areas, they preyed heavily on lobsters (Randall 1967), which were totally absent in the 154 stomachs sampled in this study. Also, contrary to the findings of Randall (1967), Randall (1983) and Bullock \& Smith (1991), no turtles or octopus and only few gastropods were observed in stomach contents. Lobsters and juvenile sea turtles were also reported in Epinephelus lanceatus (Bloch, 1790), the second largest grouper in the world (Heemstra \& Randall 1993). No predation on young turtles was found in French Guiana, even though French Guiana is one of the most important areas for turtle emergence (Dermochelys coriacea, Chelonia mydas and Eretmochelys imbricata) in the Caribbean (Girondot \& Fretey 1996).

The diet of goliath groupers was therefore less diverse in French Guiana than in the Caribbean (Randall 1983) or Florida (Koenig \& Coleman 2012). 
Because the abundance and availability of potential prey for goliath grouper is unknown in French Guiana, it is not possible to determine whether the low diversity in the diet is due to low prey diversity or to difficulty in finding prey in turbid water. Coastal waters in French Guiana are extremely turbid, with visibility measured in centimeters rather than meters. Sediments from the Amazon are transported northwest to French Guiana by the Guiana Current (Muller-Karger et al. 1988, Gratiot et al. 2008), so coastal marine organisms here likely encounter prey primarily by smell, hearing and lateral line sense, rather than by sight (Janssen et al. 1995, Montgomery et al. 1995, Hartman \& Abrahams 2000). Utne-Palm (2002) demonstrated that turbidity affects foraging behaviour by increasing the search time and decreasing the reactive distance, thus reducing the catchability of prey for piscivorous fishes. In other words, more diverse food (pelagic fish, juvenile sea turtles) may not have been available to goliath grouper because they probably could not see them.

Goliath grouper $\delta^{15} \mathrm{~N}$ values appear equivalent to those of a tertiary consumer (Fig. 8), but more potential food sources need to be collected to confirm this result. This species has no known predator, except maybe large sharks (Sadovy \& Eklund 1999), so it may be characterized as a top predator in the waters off French Guiana.

The half-life of carbon in goliath grouper white muscle was estimated to be between 151 and $289 \mathrm{~d}$, depending on size. Since the half-life of carbon indicates the duration of integration in the diet, $\delta^{13} \mathrm{C}$ values for goliath grouper reflect the diet assimilated over about 1 or more years. The carbon and nitrogen stable isotope signatures did not differ among the 3 study sites or between the 2 seasons for either goliath groupers or their prey (crustaceans and teleost fishes). Because the white muscle turnover rate of goliath grouper exceeds the duration of a single season, it was not possible to evaluate a seasonal change in diet using stable isotopes. Furthermore, no seasonal variation in stomach contents was evident. Presumably, seasonal patterns of wet and dry conditions do not appreciably change the trophic patterns in waters off French Guiana. Indeed, variations induced by tide cycles added to shallow depth $(<15 \mathrm{~m})$, promote the mixing of water columns during the entire year (Pujos \& Froidefond 1995, Bourret et al. 2005, 2008, Chevalier et al. 2008). The benthic diversity is low in coastal areas, and fish diversity remains unchanged year round with a constant food supply (Gray 2002, Schvartz 2011).
Feeding behaviour

The sea basses and groupers (Serranidae) are described as diurnal or crepuscular predators (Meurer \& Andreata 2002, Gibran 2007). However, some species, for example the dusky grouper (Epinephelus marginatus Lowe, 1834), may also feed nocturnally (Gibran 2007). No pattern between time of day and vacuity coefficient or digestion rate was found with goliath grouper. However, sampling was not conducted at night, and potential differences in diet between day and night could not be verified. In the same way, there was no relationship between the food intake of goliath grouper and the tidal cycle.

Ninety-three percent of prey items found in goliath grouper stomachs in French Guiana were demersal species. Thus, goliath groupers feed primarily on the bottom, a behaviour observed in other studies (Randall 1967, Bullock \& Smith 1991, Sadovy \& Eklund 1999, Gerhardinger et al. 2006). Many of the fish prey species found in the samples occur on mud bottoms near rocky areas, suggesting that goliath groupers do not venture far from home sites to feed, a behaviour observed in juveniles $(<120 \mathrm{~cm})$ by Koenig et al. (2007). Slow-moving prey, such as catfish and crabs, were more common in the diet of goliath grouper than rapidly moving prey, such as species in the family Sciaenidae, although they all live in the same areas as goliath groupers (C. Artero pers. obs.). Goliath groupers, as other grouper species, seem to be ambush predators (Randall 1967, Colette \& Talbot 1972) with a 'lie in wait' feeding strategy, i.e. they wait for prey to approach, then charge and engulf them with their large mouths (Gibran 2007).

\section{Ontogenetic change in diet}

This study shows that the diet of goliath grouper in French Guiana changes relative to size. First, correlation of the coefficient of vacuity with size suggests that small individuals eat more often than larger ones; second, individuals $<120 \mathrm{~cm}$ have twice the number of prey items in their stomach than individuals $>120 \mathrm{~cm}$; third, carbon and nitrogen stable isotope values increase with size in goliath grouper; and fourth, crustaceans are much more abundant in goliath grouper $<120 \mathrm{~cm}$ than they are in larger specimens.

$\delta^{15} \mathrm{~N}$ values increase with fish size, for the most part because larger groupers can eat larger prey that may 
occupy higher trophic levels (Badalamenti et al. 2002, Reñones et al. 2002, Linde et al. 2004). $\delta^{13} \mathrm{C}$ values also increase with the size of goliath groupers. Such increase in $\delta^{13} \mathrm{C}$ values with size was not found in dusky grouper (Reñones et al. 2002), but was found in other fish species. For goliath grouper, this can be explained by a shift in food source. Individuals gradually increase their dependence on larger fish prey and decrease dependence on crustacean prey (or prey from other habitats) as they grow. Machado et al. (2008) reported a similar tendency for dusky grouper from southern Brazil. It is possible that goliath groupers' nutritional requirements are satisfied by preying on larger prey rather than on more prey as suggested by Machado et al. (2008) for dusky grouper.

The size-related changes highlighted in the present study (crustacean-based to fish-based diet) have not previously been reported for goliath grouper. In other studies, goliath grouper were shown to feed on lobsters and crabs even during the adult phase (Randall 1967, 1983, Bullock \& Smith 1991, Koenig \& Coleman 2009). As there is a lack of knowledge on crustacean abundance and diversity in French Guiana, it is impossible to determine the availability of such prey species to various sizes of goliath grouper. Nevertheless, dietary shifts are known to occur in groupers (e.g. Derbal \& Kara 1996, Harmelin \& Harmelin-Vivien 1999, Reñones et al. 2002, Linde et al. 2004) and other fishes (e.g. St John 1999). Linde et al. (2004) demonstrated that the diet of dusky grouper $(<50 \mathrm{~cm})$ was dominated by crustaceans, while the proportion of cephalopods and other taxa increased with size (maximum size: $105 \mathrm{~cm}$ ). The gradual ontogenetic dietary change seen in goliath grouper in French Guiana suggests that diet is related to habitat conditions and prey availability within this habitat. The fish live in high-turbidity water on rocky reefs around rocky islands. In this habitat, small groupers may be able to access and feed in small nooks in and under rocks where crabs can be found, whereas larger groupers may feed on mud surrounding the rocks, an area more frequently visited by fishes. As the grouper grows, the nooks become less accessible and the fish venture further from the protection of the rocks because of a decrease in predation risk (Wootton 1990). Gradually the mud bottom around the rocks becomes their dominant foraging habitat. Since vision is useless in the search for prey in the waters of French Guiana, only prey within close range are eaten because only those prey can be sensed.
Niche breadth

Levins' (1968) niche breadth measure, although commonly used in ecology, does not give the true range of an organism's diet in comparison to available food resources (Saikia 2012). Nevertheless, when Levins' index is combined with Tokeshi (1991) graphics, it is clear that goliath groupers are generalist feeders with a wide trophic niche. As a goliath grouper begins to catch larger prey, it changes from homogeneous (1 or 2 major prey species) to heterogeneous feeding (a greater variety of species). Biplots of $\delta^{13} \mathrm{C}$ and $\delta^{15} \mathrm{~N}$, being a representation of isotopic niche use of ontogenetically distinct groups (Hammerschlag-Peyer et al. 2011), also highlight the progressive niche shift of goliath grouper. Small goliath groupers have half the niche breadth of larger individuals. This could be due to the extremely territorial behaviour of small goliath groupers (Koenig et al. 2007). Juveniles (<100 $\mathrm{cm} L_{\mathrm{T}}$ ) are known to occupy a small home range in mangroves (Koenig et al. 2007). Goliath grouper in French Guiana may behave similarly and therefore exploit a limited area and a limited food resource. However, as the fish grow and the predation risk decreases, they are capable of exploiting a wider variety of food resources (Reñones et al. 2002). The typical pattern of goliath grouper development, as described by Koenig et al. (2007), is that the first $5 \mathrm{yr}$ of life are confined to mangrove habitat (maximum size: $100 \mathrm{~cm}$ $L_{\mathrm{T}}$ ). The fish then move offshore to join the adult population. However, in French Guiana, this pattern is somewhat altered because juveniles $>38 \mathrm{~cm}$ and adults are found offshore, around rocky islands. Under these conditions, the ontogenetic shift in diet may facilitate this pattern of a wide range of sizes living together by partitioning of food resources.

\section{Ontogenetic habitat shift}

Tagging methods are not always sufficient for determining movement between juvenile and adult habitats because of the high numbers of individuals that must be tagged to get a significant sample size (Gillanders et al. 2003). Nagelkerken \& van der Velde (2004b) used stable isotopes to discriminate feeding habitats (mangroves and seagrass beds) of different fish species. In the present study, one-third of individuals $<115 \mathrm{~cm}$ (20 individuals of 62 in total) presented isotopic values that were not explained by feeding on crustaceans or teleosts living near rocky sites. Indeed, isotopic values of $\delta^{13} \mathrm{C}$ in identified 
prey items ranged between -16.2 and $-14 \%$, which was a smaller range than expected $\left(\delta^{13} \mathrm{C}\right.$ of expected prey ranged from -20 to $-12.5 \%$ ). Several hypotheses could explain this pattern: (1) goliath groupers feed on prey that were not identified or (2) captured goliath groupers had migrated from another habitat where the baseline of isotopic values was different. As stomach contents did not reveal important food sources other than crustaceans or teleosts, habitat change among individuals $<115 \mathrm{~cm}$ seems to be the most probable explanation. Expected $\delta^{13} \mathrm{C}$ values of prey from these small groupers ranged from -20 to $-16.2 \%$. Those values correspond to the carbon isotope range ( -27 to $-15 \%$ ) of fish food items found by Nagelkerken \& van der Velde (2004a) in Caribbean mangroves. Moreover, Nakamura et al. (2008) found that fish with carbon stable isotope signatures less than $-16 \%$ o (-23 to $-17 \%$ ) were derived from mangrove habitats, similar to the isotopic values that are not explained in this study. Other stable isotope studies conducted on fish in mangroves also show depleted carbon signatures (Rodelli et al. 1984, Marguillier et al. 1997, Lee 2000, Sheaves \& Molony 2000). Thus, mangroves are environments where there is a depletion of ${ }^{13} \mathrm{C}$ (Lugendo et al. 2006). Because the carbon signature of some small goliath groupers could reflect a diet of prey living in mangroves, it is likely that some groupers living around rocky sites migrate from mangroves to rocky sites.

Correspondingly, prey of goliath groupers with $\delta^{13} \mathrm{C}$ values above $-12.8 \%$ (comprising 50 individuals from all size classes) were not identified. Since lipids were not removed for the isotopic analysis of prey, $\delta^{13} \mathrm{C}$ values of fat prey could be higher than expected.

Mangrove habitats are often characterized by a high density of juveniles and are therefore referred to as a nursery habitat (Robertson \& Duke 1987, Little et al. 1988, Parrish 1989). Moreover, it is well documented that goliath grouper juveniles first grow in mangroves before migration to their adult habitat (Bullock et al. 1992, Koenig et al. 2007, Lara et al. 2009). Mangroves cover the major part of the coasts of French Guiana, but currently no investigations into a possible link between juvenile goliath groupers and mangroves are available. In this study, based on $\delta^{13} \mathrm{C}$ values, about one-third of the small groupers sampled seemed to have recently migrated from mangrove habitats. The other two-thirds were probably long-time residents of the rocky habitat in which they were sampled (the smallest grouper caught in rocky habitat, not included in the analyzed sample, measured $38 \mathrm{~cm}$ ). Thus, it is possible that goliath groupers in French Guiana could settle in mangroves or rocky reefs, but also that very small goliath groupers could be driven from mangroves to offshore rocky reefs by excessive freshwater during the rainy season (salinity of 6 near mangroves during the rainy season; C. Dupuy pers. comm.). A comprehensive inventory of animals living in mangroves should confirm the presence of small groupers. In general, mangroves in French Guiana should be studied further to determine their importance as a nursery ground for goliath grouper and other species and to ensure continued production of these ecologically and economically important species.

Acknowledgements. This study was carried out in partial fulfilment of C.A.'s doctoral degree in marine biology at the University of French West Indies and French Guiana. We thank the Grand Connétable Reserve agents A. Alcide and A. Hauselmann for providing access to the field and the reserve in their research vessel; the Association des Plaisanciers et Pêcheurs de Guyane (APPG), especially E. Ribas, for his involvement and support in the grouper project; N. Cozannet for her help in the field and for helping with prey identification; and P. Perrichon, T. Bui and C. Dupuy for their hospitality during my trip in La Rochelle (C.A.). We also thank the Direction de l'Environnement, de l'Aménagement et du Logement (DEAL) for supporting the research and the Office National de la Chasse et de la Faune Sauvage (ONCFS) for the administrative and financial management of the grouper project.

\section{LITERATURE CITED}

Ankjærø T, Christensen JT, Grønkjær P (2012) Tissuespecific turnover rates and trophic enrichment of stable $\mathrm{N}$ and $\mathrm{C}$ isotopes in juvenile Atlantic cod Gadus morhua fed three different diets. Mar Ecol Prog Ser 461:197-209

Badalamenti F, D'Anna G, Pinnegar JK, Polunin NVC (2002) Size-related trophodynamic changes in three target fish species recovering from intensive trawling. Mar Biol 141: 561-570

Bourret A, Devenon JL, Chevalier C (2005) Investigation on passive open boundary conditions adapted to the conjunction of strong currents, standing tidal wave and high stratification: application to the French Guiana continental shelf. Cont Shelf Res 25:1353-1373

Bourret A, Devenon JL, Chevalier C (2008) Tidal influence on the hydrodynamics of the French Guiana continental shelf. Cont Shelf Res 28:951-961

Buchheister A, Latour RJ (2010) Turnover and fractionation of carbon and nitrogen stable isotopes in tissues of a migratory coastal predator, summer flounder (Paralichthys dentatus). Can J Fish Aquat Sci 67:445-461

Bullock LH, Smith GB (1991) Seabasses (Pisces: Serranidae). Memoirs of the Hourglass Cruises. Florida Marine Research Institute, St Petersburg, FL

Bullock LH, Godcharles MF, Mitchell ME (1992) Age, growth and reproduction of jewfish Epinephelus itajara in the eastern Gulf of Mexico. Fish Bull 90:243-249

Bunn SE, Loneragan NR, Kempster MA (1995) Effects of acid washing on stable isotope ratios of $\mathrm{C}$ and $\mathrm{N}$ in 
penaeid shrimp and seagrass: implications for food-web studies using multiple stable isotopes. Limnol Oceanogr 40:622-625

Burress ED, Duarte A, Serra WS, Gangloff MM, Siefferman L (2013) Species-specific ontogenetic diet shifts among neotropical Crenicichla: using stable isotopes and tissue stoichiometry. J Fish Biol 82:1904-1915

Chevalier C, Froidefond JM, Devenon JL (2008) Numerical analysis of the combined action of littoral current, tide and waves on the suspended mud transport and on turbid plumes around French Guiana mudbanks. Cont Shelf Res 28:545-560

Chouvelon T, Spitz J, Cherel Y, Caurant F, Sirmel R, Mèndez-Fernandez P, Bustamante P (2011) Inter-specific and ontogenic differences in $\delta^{13} \mathrm{C}$ and $\delta^{15} \mathrm{~N}$ values and $\mathrm{Hg}$ and $\mathrm{Cd}$ concentrations in cephalopods. Mar Ecol Prog Ser 433:107-120

Cocheret de la Morinière E, Pollux BJA, Nagelkerken I, Hemminga MA, Huiskes AHL, van der Velde G (2003) Ontogenetic dietary changes of coral reef fishes in the mangrove-seagrass-reef continuum: stable isotopes and gut-content analysis. Mar Ecol Prog Ser 246:279-289

Colette BB, Talbot FH (1972) Activity patterns of coral reef fishes with emphasis on nocturnal-diurnal changeover. Sci Bull Nat Hist Mus 14:98-124

Cortés E (1997) A critical review of methods of studying fish feeding based on analysis of stomach contents: application to elasmobranch fishes. Can J Fish Aquat Sci 54: 726-738

Costello MJ (1990) Predator feeding strategy and prey importance: a new graphical analysis. J Fish Biol 36: 261-263

Craig MT (2011) Epinephelus itajara. The IUCN Red List of Threatened Species, Version 2014.2. www.iucnredlist.org (accessed 13 October 2014)

DeNiro MJ, Epstein S (1977) Mechanism of carbon isotope fractionation associated with lipid synthesis. Science 197: 261-263

DeNiro MJ, Epstein S (1978) Influence of diet on the distribution of carbon isotopes in animals. Geochim Cosmochim Acta 42:495-506

Derbal F, Kara MH (1996) Alimentation estivale du mérou, Epinephelus marginatus (Serranidae), des côtes est algeriennes. Cybium 20:295-301

Eggleston DB, Grover JJ, Lipcius RN (1998) Ontogenetic diet shifts in Nassau grouper: trophic linkages and predatory impact. Bull Mar Sci 63:111-126

Fischer W (ed) (1978) FAO species identification sheets for fishery purposes. Western central Atlantic (fishing area 31), Vol 6. FAO, Rome

Focken U, Becker K (1998) Metabolic fractionation of stable carbon isotopes: implications of different proximate compositions for studies of the aquatic food webs using $\delta^{13} \mathrm{C}$ data. Oecologia 115:337-343

Fry B (1988) Food web structure on Georges Bank from stable $\mathrm{C}, \mathrm{N}$, and $\mathrm{S}$ isotopic compositions. Limnol Oceanogr 33:1182-1190

Fry B (2006) Stable isotopes ecology. Springer, New York, NY

Fry B, Mumford PL, Robblee MB (1999) Stable isotope studies of pink shrimp (Farfantepenaeus duorarum Burkenroad) migrations on the southwestern Florida shelf. Bull Mar Sci 65:419-430

Gerhardinger LC, Marenzi RC, Bertoncini ÁA, Medeiros RP, Hostim-Silva M (2006) Local ecological knowledge on the goliath grouper Epinephelus itajara (Teleostei: Serranidae) in southern Brazil. Neotrop Ichthyol 4:441-450

Gibran FZ (2007) Activity, habitat use, feeding behavior, and diet of four sympatric species of Serranidae (Actinopterygii: Perciformes) in southeastern Brazil. Neotrop Ichthyol 5:387-398

Gillanders BM, Able KW, Brown JA, Eggleston DB, Sheridan PF (2003) Evidence of connectivity between juvenile and adult habitats for mobile marine fauna: an important component of nurseries. Mar Ecol Prog Ser 247:281-295

Girondot M, Fretey J (1996) Leatherback turtles, Dermochelys coriacea, nesting in French Guiana, 1978-1995. Chelonian Conserv Biol 2:204-208

Gratiot N, Anthony EJ, Gardel A, Gaucherel C, Proisy C, Wells JT (2008) Significant contribution of the 18.6 year tidal cycle to regional coastal changes. Nat Geosci 1: 169-172

Gray J (2002) Antarctic marine benthic biodiversity in a world-wide latitudinal context. In: Arntz W, Clarke A (eds) Ecological studies in the Antarctic sea ice zone. Springer, Heidelberg, p 1-9

Guelinckx J, Maes J, Van Den Driessche P, Geysen B, Dehairs F, Ollevier F (2007) Changes in $\delta^{13} \mathrm{C}$ and $\delta^{15} \mathrm{~N}$ in different tissues of juvenile sand goby Pomatoschistus minutus: a laboratory diet switch experiment. Mar Ecol Prog Ser 341:205-215

Hammerschlag-Peyer CM, Yeager LA, Araújo MS, Layman CA (2011) A hypothesis-testing framework for studies investigating ontogenetic niche shifts using stable isotope ratios. PLoS ONE 6:e27104

Harmelin JG, Harmelin-Vivien M (1999) A review on habitat, diet and growth of the dusky grouper, Epinephelus marginatus (Lowe, 1834). Mar Life 9:11-20

Hartman EJ, Abrahams MV (2000) Sensory compensation and the detection of predators: the interaction between chemical and visual information. Proc R Soc B 267: 571-575

Heemstra PC, Randall JE (1993) FAO species catalogue. Groupers of the world (family Serranidae, subfamily Epinephelinae). An annotated and illustrated catalogue of the grouper, rockcod, hind, coral grouper and lyretail species known to date. FAO Fisheries Synopsis No. 125, Vol 16. FAO, Rome

Hobson KA (1999) Tracing origins and migration of wildlife using stable isotopes: a review. Oecologia 120:314-326

Hobson KA, Clark RG (1992) Assessing avian diets using stable isotopes. I. Turnover of ${ }^{13} \mathrm{C}$ in tissues. Condor 94 : 181-188

Horn HS (1966) Measurement of 'overlap' in comparative ecological studies. Am Nat 100:419-424

Hostim-Silva M, Bertoncini AA, Gerhardinger LC, Machado LF (2005) The 'lord of the rock's' conservation program in Brazil: the need for a new perception of marine fishes. Coral Reefs 24:74

Hyslop EJ (1980) Stomach contents analysis - a review of methods and their application. J Fish Biol 17:411-429

Jacob U, Mintenbeck K, Brey T, Knust R, Beyer K (2005) Stable isotope food web studies: a case for standardized sample treatment. Mar Ecol Prog Ser 287:251-253

Janssen J, Jones WR, Whang A, Oshel PE (1995) Use of the lateral line in particulate feeding in the dark by juvenile alewife (Alosa pseudoharengus). Can J Fish Aquat Sci 52:358-363

Kamler JF, Pope KL (2001) Nonlethal methods of examining fish stomach contents. Rev Fish Sci 9:1-11 
Koenig CC, Coleman FC (2009) Population density, demographics and predation effects of adults goliath grouper. National Oceanic and Atmospheric Administration, Miami, FL

Koenig CC, Coleman FC (2012) Goliath grouper (Epinephelus itajara). www.marinelab.fsu.edu (accessed 16 March 2015)

Koenig CC, Coleman FC, Eklund AM, Schull J, Ueland J (2007) Mangroves as essential nursery habitat for goliath grouper (Epinephelus itajara). Bull Mar Sci 80:567-586

Krebs CJ (1989) Ecological methodology. Harper and Row Publishers, New York, NY

Lara MR, Schull J, Jones DL, Allman R (2009) Early life history stages of goliath grouper Epinephelus itajara (Pisces: Epinephelidae) from Ten Thousand Islands, Florida. Endang Species Res 7:221-228

Lee SY (2000) Carbon dynamics of Deep Bay, eastern Pearl River estuary, China. II. Trophic relationship based on carbon- and nitrogen-stable isotopes. Mar Ecol Prog Ser 205:1-10

Léopold M (2005) Guide des poissons de mer de guyane. Ifremer, Plouzané

Levins R (1968) Evolution in changing environments: some theoretical explorations. Princeton University Press, Princeton, NJ

Liao H, Pierce CL, Larscheid JG (2001) Empirical assessment of indices of prey importance in the diets of predacious fish. Trans Am Fish Soc 130:583-591

Lichtenstein MGG (1822) Die Werke von Marcgrave und Piso über die Naturgeschichte Brasiliens, erläutert aus den wieder aufgefundenen Originalzeichnungen. Abbildungen IV Fische. Abh K Akad Wiss Berlin 1820-21: 238-254

Linde M, Grau AM, Riera F, Massutí-Pascual E (2004) Analysis of trophic ontogeny in Epinephelus marginatus (Serranidae). Cybium 28:27-35

Little MC, Reay PJ, Grove SJ (1988) The fish community of an East African mangrove creek. J Fish Biol 32:729-747

Longley WH, Hildebrand SF (1941) Systematic catalogue of the fishes of Tortugas, Florida with observations on color, habits, and local distribution. Pap Tortugas Lab 34:1-331

Lugendo BR, Nagelkerken I, van der Velde G, Mgaya YD (2006) The importance of mangroves, mud and sand flats, and seagrass beds as feeding areas for juvenile fishes in Chwaka Bay, Zanzibar: gut content and stable isotope analyses. J Fish Biol 69:1639-1661

Machado LF, Daros FAML, Andrade Bertoncini Á, HostimSilva M, Barreiros JP (2008) Feeding strategy and trophic ontogeny in Epinephelus marginatus (Serranidae) from southern Brazil. Cybium 32:33-41

Marguillier S, van der Velde G, Dehairs F, Hemminga MA, Rajagopal S (1997) Trophic relationships in an interlinked mangrove-seagrass ecosystem as traced by $\delta^{13} \mathrm{C}$ and $\delta^{15}$ N. Mar Ecol Prog Ser 151:115-121

McClenachan L (2009) Historical declines of goliath grouper populations in South Florida, USA. Endang Species Res 7:175-181

Meurer BC, Andreata JV (2002) Hábito alimentar de Diplectrum radiale (Quoy \& Gaimard, 1824; Teleostei, Perciformes, Serranidae) na Baía da Ribeira, Angra dos Reis, Rio de Janeiro, Brasil. Arqu Mus Nac, Rio 60:315-320

Montgomery J, Coombs S, Halstead M (1995) Biology of the mechanosensory lateral line in fishes. Rev Fish Biol Fish 5:399-416

Morisita M (1959) Measuring of interspecific association and similarity between communities. Mem Fac Sci Kyushu Univ Ser E Biol 2:215-235

Muller-Karger FE, McClain CR, Richardson PL (1988) The dispersal of the Amazon's water. Nature 333:56-59

Murie DJ, Parkyn DC, Koenig CC, Coleman FC, Schull J, Frias-Torres S (2009) Evaluation of finrays as a non-lethal ageing method for protected goliath grouper Epinephelus itajara. Endang Species Res 7:213-220

Nagelkerken I, van der Velde G (2004a) Are Caribbean mangroves important feeding grounds for juvenile reef fish from adjacent seagrass beds? Mar Ecol Prog Ser 274: 143-151

Nagelkerken I, van der Velde G (2004b) Relative importance of interlinked mangroves and seagrass beds as feeding habitats for juvenile reef fish on a Caribbean island. Mar Ecol Prog Ser 274:153-159

Nakamura Y, Horinouchi M, Shibuno T, Tanaka Y and others (2008) Evidence of ontogenetic migration from mangroves to coral reefs by black-tail snapper Lutjanus fulvus: stable isotope approach. Mar Ecol Prog Ser 355: $257-266$

Navia AF, Mejia-Falla PA, Giraldo A (2007) Feeding ecology of elasmobranch fishes in coastal waters of the Colombian eastern tropical Pacific. BMC Ecol 7:8-18

Nieuwenhuize J, Maas YEM, Middelburg JJ (1994) Rapid analysis of organic carbon and nitrogen in particulate materials. Mar Chem 45:217-224

NMFS (National Marine Fisheries Service) (2006) Status report on the continental United States distinct population segment of the goliath grouper (Epinephelus itajara), Florida. NMFS, St. Petersburg, FL

Odum WE (1971) Pathways of energy flow in a southern Florida estuary. Sea Grant Tech Bull Miami Univ 7:162

Parrish JD (1989) Fish communities of interacting shallowwater habitats in tropical oceanic regions. Mar Ecol Prog Ser 58:143-160

Pina-Amargós F, González-Sansón G (2009) Movement patterns of goliath grouper Epinephelus itajara around southeast Cuba: implications for conservation. Endang Species Res 7:243-247

Pinkas L, Oliphant MS, Iverson ILK (1971) Food habits of albacore, bluefin tuna, and bonito in California waters. California Department of Fish and Game

Pinnegar JK, Polunin NVC (1999) Differential fractionation of $\delta^{13} \mathrm{C}$ and $\delta^{15} \mathrm{~N}$ among fish tissues: implications for the study of trophic interactions. Funct Ecol 13:225-231

Post DM (2002) Using stable isotopes to estimate trophic position: models, methods, and assumptions. Ecology 83: 703-718

Pujos M, Froidefond JM (1995) Water masses and suspended matter circulation on the French Guiana continental shelf. Cont Shelf Res 15:1157-1171

Randall JE (1967) Food habits of reef fishes of West Indies. Stud Trop Oceanogr 5:665-847

Randall JE (1983) Caribbean reef fishes. T.F.H. Publications, Neptune City, NJ

Reñones O, Polunin NVC, Goni R (2002) Size related dietary shifts of Epinephelus marginatus in a western Mediterranean littoral ecosystem: an isotope and stomach content analysis. J Fish Biol 61:122-137

Robertson AI, Duke NC (1987) Mangroves as nursery sites: comparisons of the abundance and species composition of fish and crustaceans in mangroves and other nearshore habitats in tropical Australia. Mar Biol 96:193-205 
Rodelli MR, Gearing JN, Gearing PJ, Marshall N, Sasekumar A (1984) Stable isotope ratio as a tracer of mangrove carbon in Malaysian ecosystems. Oecologia 61:326-333

Rosecchi E, Nouaze Y (1987) Comparaison de cinq indices alimentaires utilisés dans l'analyse des contenus stomacaux. Rev Trav Inst Pêches Marit 49:111-123

Sadovy Y, Eklund AM (1999) Synopsis of biological data on the Nassau grouper, Epinephelus striatus (Bloch, 1792), and the jewfish, E. itajara (Lichtenstein, 1822). US Department of Commerce, Washington, DC

Saikia SK (2012) Proposal of a new and simple descriptive measure of diet breadth. Ecologia 2:85-92

Schvartz T (2011) Appel à projet-biodiversité marine en Guyane française (année 2009) — réalisation d'une campagne d'inventaire de la faune benthique (endogée et épigée) et démersale, sur les fonds marins du plateau continental guyanais. Creocean, Montpellier

Sheaves M, Molony B (2000) Short-circuit in the mangrove food chain. Mar Ecol Prog Ser 199:97-109

St John J (1999) Ontogenetic changes in the diet of the coral reef grouper Plectropomus leopardus (Serranidae): patterns in taxa, size and habitat of prey. Mar Ecol Prog Ser 180:233-246

Sweeting CJ, Barry J, Barnes C, Polunin NVC, Jennings S

Editorial responsibility: Eduardo Martins,

Vancouver, British Columbia, Canada
(2007) Effects of body size and environment on diettissue $\delta^{15} \mathrm{~N}$ fractionation in fishes. J Exp Mar Biol Ecol 340:1-10

Takeda M, Okutani T (1983) Crustaceans and mollusks trawled off Suriname and French Guiana. Japan Marine Fishery Resource Research Center, Tokyo

Tieszen LL, Boutton TW, Tesdahl KG, Slade NA (1983) Fractionation and turnover of stable carbon isotopes in animal tissues: implications for $\delta^{13} \mathrm{C}$ analysis of diet. Oecologia 57:32-37

Tokeshi M (1991) Graphical analysis of predator feeding strategy and prey importance. Freshw Forum 1:179-183

Utne-Palm AC (2002) Visual feeding of fish in a turbid environment: physical and behavioural aspects. Mar Freshw Behav Physiol 35:111-128

Weidel BC, Carpenter SR, Kitchell JF, Vander Zanden MJ (2011) Rates and components of carbon turnover in fish muscle: insights from bioenergetics models and a wholelake ${ }^{13} \mathrm{C}$ addition. Can J Fish Aquat Sci 68:387-399

Wootton RJ (1990) Ecology of teleost fishes. Chapman \& Hall, London

Zuev GV, Nigmatullin CM, Nikolsky VN (1985) Nektonic oceanic squids (genus Stenoteuthis). Agropromizdat, Moscow

Submitted: April 28, 2014; Accepted: November 24, 2014 Proofs received from author(s): March 18, 2015 